\title{
ウォルマートの創造的な連続適応型 新規業態開発志向現地化戦略
}

丸 谷 雄一郎

(東京経済大学)

\section{要約（アブストラクト）}

小売国際化研究は 1990 年代以降理論的課題の提示と分析モデル構築という概念化段階に達した。矢作 (2007) は、日米欧韓の小売企業の東アジアでの小売事業モデルの現地化のケースをつみあげることにより、 初期参入段階を踏まえた上での現地化段階での戦略パターン解明をグローバル統合段階をも意識しながら 行っている。

本研究は矢作 (2007) とは手法が異なるが、矢作 (2007) の枠組みに依拠し、世界最大の売上高を誇り、更な る国際展開を進め、現地化段階からグローバル統合段階を目指しつつある、ウオルマートのラテンアメリカ 地域、特にメキシコ市場での低所得階層を主要標的とするボデーガ業態の開発を主要分析対象とした。新規 業態開発志向の現地化戦略に関して解明を試み、創造的な連続適応型の新規業態開発志向現地化の成功事例 として位置づけた。

キーワード

小売国際化、創造的な連続適応、新規業態開発志向、現地化戦略、ウォルマート、メキシコ、ラテンアメリカ、 ボデーガ

\section{1. 問題意識}

1990 年代グローバル・リテイラーと呼ば れる小売業者の国際展開がもてはやされた。 日本でもトイザラスの進出以降、イケア、ザ ラ、HMV など専門業態を展開する小売業者 から、ウォルマート、カルフール、テスコ、 コストコなど食品も取り扱う総合業態を展 開する小売業者まで、グローバル・リテイ ラーと呼ばれる業者の進出が相次いだ。しか し、現実には多くの企業は苦戦して軸足を新 興市場へ移し、新興市場でも成功しているの は一部の企業に限られている。

Corstjens and Lal (2012)の食料品取り扱
い小売業者の国際化に関する研究でも、小売 業者の国際化による効果は少なくとも短期 的収益貢献については懐疑的であることを 示しており、鈴木 (1976) で示された小売業 特有の困難さについて何も変わっていない ことがわかる。

本研究は製造業者に比べて困難といわれ る小売業者の国際化に打いて、成功事例とな りつつあるウォルマートの新規業態開発志 向現地化について示すことによって、小売国 際化プロセス概念化の精緻化に貢献するこ とを目的としている。 


\section{2. 本研究の位置づけ}

\section{（1）小売国際化研究の現状}

小売国際化に関する研究は 1990 年代以降 グローバル・リテーラーの存在感が各国市 場で拡大する中で活発になった。欧米では 小売国際化に関するテキストが刊行された (Alexander 1997、Sternquist 1998)。日本 でも、向山 (1996)、川端 (2000)、矢作 (2007)、 青木 (2008)、金(2008) など多くの研究がな された。小売国際化の既存研究は、現状の把 握、分析の焦点化、概念化というプロセスを 経てなされた。現在では国際化プロセスの概 念化に向けた努力がなされて打り、深澤他 (2008)にみられるように、戦略的分析フレー ムワーク構築に向けた取り組みもなされて きている。

小売国際化プロセスは時間を追って参入 前の事業化調査から始まり、参入、参入後の 事業活動と評価と進展する。矢作 (2007) は Douglas and Craig(1995) が提示する (1)初期 参入、(2)現地化、(3)グローバル統合という国 際化プロセスの 3 段階の分類を用いて、初期 参入段階を踏まえた上での現地化段階の戦 略パターン解明を行っており、問題意識は筆 者と全く共通している。しかし、筆者がウオ ルマート 1 社を中心にとりあげ、同社の進 出地域ごとの現地化パターンについて詳細 に検討しているのに対し、矢作は日米欧韓の 小売企業の東アジアでの小売事業モデルの 現地化のケースをつみあげて検討しており、 検討手法は異なる。

とはいえ、矢作 (2007) は分析対象として ウォルマートと類似した現地化パターンに よって小売事業モデルの国際移転を行った テスコなどの検討を通じて、小売国際化のう ち現地化段階の分析において、非常に有用な 枠組みを提供している。ゆえに、本稿は矢作 (2007)の枠組みに依拠し検討していく。
矢作 (2007) は、Vida and Fairhurst (1998)、 Alexander and Myers (2000)をべースに自身 でアレンジした小売国際化の組織行動モデ ルと、このモデルのサブシステムとしての 小売事業モデルを示した上で、Douglas and Craig (1995)のいうところの現地化段階に焦 点を絞って検討を行い、(1)完全なる標準化志 向(例：高級アパレルショップ)、(2)標準化 のなかの部分適応 (例 : 後発国への伝統的な HM、GMS 参入)、(3)創造的な連続適応 (例 : セブンイレブン・ジャパン)、(4)新規業態開 発志向(例：欧州以外のテスコ)という 4 つ の現地化パターンを提示した。

筆者の主要な分析対象地域であるメキシ コに打いても、成功事例の多くは適応の必要 性が低い(1) (完全なる標準化志向)・(2)(標準 化のなかの部分適応)に位置しており、例え ば大手小売企業ヒガンテとの提携によって 店舗展開してきたオフィスデポ、ラディオ シャックなどのカテゴリーキラーやグロー バルニッチを狙うSPAの ZARA など一部 例外的にみられるにすぎない。

(3) (創造的な連続適応) ・ (4) (新規業態開発 志向)の強い企業はウォルマート以外には現 状では存在感が小さく、(2) (標準化のなかの 部分適応) を志向したウォルマートのライバ ルであったカルフールは、既にメキシコの中 堅チェーンのチェドラウイに店舗を売却し 撤退している。

\section{（2）ウォルマートの国際化研究}

ウォルマートの国際化研究は同社の国際 化とともに多くなされており (Brunn 2006、 など)、メキシコの事例は(2)(標準化のなかの 部分適応）の成功事例として多く執筆され た(Hill 2004、Thomas and Gonzalez 2006、 Durand 2007 など)。筆者も当初(2) (標準化 のなかの部分適応)の成功事例として、初期 
参入段階における意思決定事項 (市場選択に 至った要因、最適パートナー選択といった参 入方法、NAFTA に至る時期の市場状況）に ついて考察を行った(丸谷 2003)。

しかし、現地調査を進めるうちに(丸谷、 大澤 2008、など)、同社の事例は(2)(標準化 のなかの部分適応)の成功事例ではなく、現 地市場の有する独自性への能動的な対応を 行った(3) (創造的な連続適応) 段階を経て、メ キシコ市場で掴んだ低価格をべースにした、 (4) (新規業態開発志向) (矢作 2007) に基づく 戦略の成功事例であることが明確となった。 そして、この事例が示すボデーガ業態開発な どのノウハウは、今後の同社のグローバル展 開においても有用であり、この戦略が進出先 現地市場に与える影響の大きさについても 着目するようになった (丸谷・大澤 2008) ${ }^{1}$ 。

\section{（3）本研究の位置づけ}

本研究は、2006 年ドイッ、韓国撤退後に 出店標的地域を BRICS など大規模新興国と 中南米諸国に絞り、一部地域で現地化段階に 入ったとみられるウォルマートを題材に、小 売国際化研究のうち新規業態開発志向の現 地化戦略について明らかにしていこうとす る試みの一部である。

なお、同社はこれらの地域において、(4) (新規業態開発志向)を強めており、こうした 兆候は NAFTA 準加盟国チリへの近年の展 開とペルー進出への布石 (丸谷 2011a)、メキ シコと中米を統括するための組織再編 (丸谷 2011c)、サブサハラ地域に幅広く展開する 企業への資本参加によるアフリカ進出 (丸谷 2012)、ブラジル、アルゼンチンへのメキシ コでの成功業態ノウハウの移転などにもみ られる。

本研究は、矢作 (2007) が提示した現地化 戦略パターンの 4 類型のうち、(4)(新規業態
開発志向) 現地化に関して、実態を検討する ことによって、一部起こりつつあるグローバ ル統合段階に打ける小売事業モデル構築に 向けた検討材料を提示すると同時に、従来の 市場と異なる市場特性を有する新興市場へ の外資参入に打ける検討課題をも明らかに することを目的としている

矢作は (4)(新規業態開発志向) 現地化に関 して、テスコの新興市場向けハイパーマー ケット業態開発事例を検討している (矢作 2007、242-275 頁)。同社は後発だったがゆ えに、進出先のパートナーの市場におけるポ ジションを引き継ぎ、進出先でのチャネルに おける主導権を獲得した上で、フランス、ハ ンガリーに打けるハイパーマーケットの運 営経験を踏まえて、タイに打いて新規業態を 開発した。この業態はワンストップショッピ ング、低価格販売、無料駐車場という従来の ハイパーマーケットの基本特性を継承しつ つも、飲食、娛楽部門や専門店テナントを拡 充し、ショッピング・センターとしての魅力 を高める競争差異化が追及された。テスコは あくまでも既に進出していた他社との競争 を意識しながら、新興市場向けの新規業態開 発を志向したために、ハイパーマーケットの 基本特性を継承した新規業態を開発してい たのである。

それに対して、ウォルマートはメキシコに おいて同業態を当時展開していたカルフー ルなど有力外資に対しては先発であり、選択 したパートナーも当時同国市場最大手の小 売企業であったため、テスコに比べて容易に 進出先でのチャネルに打ける主導権を獲得 しやすかった。そのため、ウォルマートはメ キシコ市場での同業他社との競争よりは、新 興市場としてのメキシコの市場特性である 圧倒的規模を有する低所得階層のニーズに 徹底的に向き合って、新規業態開発を志向し 
た。新規業態の元のアイデアは買収先企業の 既存業態である、スペイン語で倉庫を意味す るボデーガにある。この業態は倉庫のよう な最低限度の内装設備の店舗というハード を、発展途上国の特徴である安価な人件費を 活かした人海戦術というソフト上の工夫に よって運営することによって、ロー・コスト・ オペレーションを実現し、若干の低価格を実 現するという業態であった。同社は買収先企 業の既存業態のアイデアから新興市場発の 倉庫型ディスカウントストア業態を開発す ることができたのである。

本稿では BRICS に次ぐ新興市場として注
目されているメキシコ市場における新興市 場発の (4)(新規業態開発志向) 現地化戦略の 事例である、ウォルマートの新興市場向け倉 庫型ディスカウントストア業態の開発事例 を検討していく。

\section{3. ウォルマートの新規業態開発志向の現} 地化戦略

（1）ウォルマートの国際市場参入戦略

(1)米国ウォルマートの小売事業モデルの概要 米国ウォルマートの小売事業モデルは以 下の通りである(図 1 参照)。

図1 ウォルマートの小売事業モデル

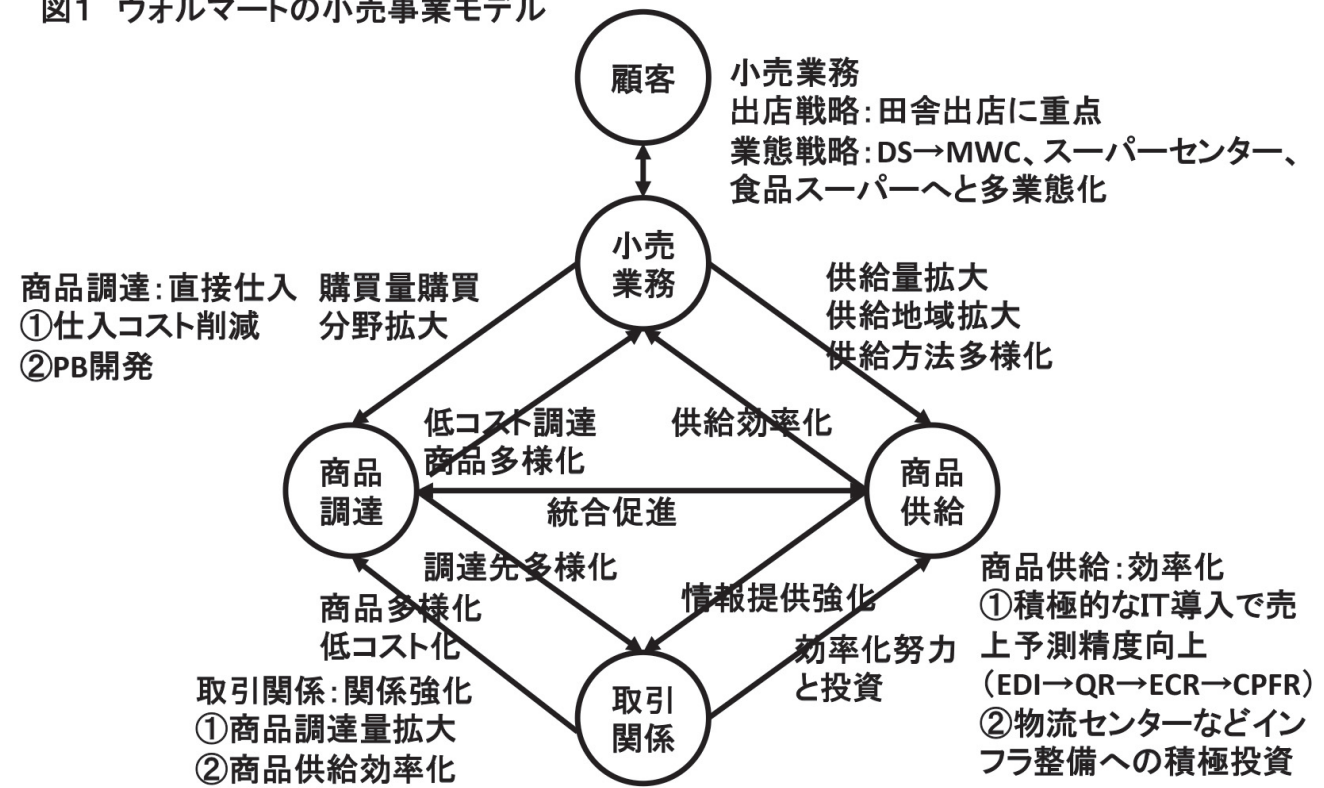

注) DSはディスカウントストア、MWCは会員制倉庫型店舗、EDIは電子データ交換、QRは クイックレスポンス、ECRは効率的顧客対応、CPFRは協力的計画予測補充である。 (出所) 矢作 $(2007 、 34$ 頁)の枠組みに基づいて、筆者が作成。

小売は「物品を卸売から買い入れて、これ を消費者に分けて売ること」であるが、小売 を事業化し、規模拡大を図っていくために は、直接的に商品・サービスを提供する小売 業務だけではなく、小売業務を後方で支える 商品調達と商品供給も重要な要素である。

ウォルマートの小売事業モデルは、本来競 合が少ない田舎での出店戦略が前提となっ ており ${ }^{3}$ 、都市部では利用可能な卸売業者や
ブローカーが田舎出店ゆえに利用が困難で あったために仕方なしに自前で行った商品 調達や商品供給の取り組みが同社の強みと なっていったものである。同社はディスカウ ントストア、MWC (会員制倉庫型店舗)、スー パーセンター、食品スーパーといった他社の 開発した小売業態を借用しつつも、同社の強 みとなった商品調達力と商品供給力を利用 して進化させ、アイデア元である他社を上回 
る成功を収める結果につなげていった。

(2)ウォルマートの国際化の経緯

ウォルマートの国際化は、常識やこれまで の方法に捕らわれないという企業文化の礎 を築き、米国本国で既述の小売事業モデルを 確立し、国際化の前提条件となる巨大母国市 場での絶対的な市場地位の構築に最大の貢 献を果たした創業者サム・ウォルトンが亡く なった後に本格的に始まった。

その成果は後継 $\mathrm{CEO}$ デイビット・グラス 以下の歴代 CEO や、国際部門強化のために 招聘されたボブ・マーチン以下の国際部門の 担当者、さらに、多くの社外からの招聘者を 含む国際部門で実績をあげた幹部によると ころが大きい。

ウォルマートの国際化は初期参入期 (1991 ～1994 年)、世界市場焦点期(1994 1999 年)、戦略視点期 (1999 2005 年)、新興市 場重視期 (2006 年〜)の 4 期に区分すること ができる ${ }^{4}$ 。新興市場重視の傾向は同社の創 業者サムの後継 2 代の CEO が米国国内事業 を院で支えた金融や物流部門からの登用で あったのに対して、2009 年に当時国際部門
担当副会長であったマイケル・デュークが国 際部門出身者として初めて CEO に就任した ことに表れている ${ }^{5}$ 。デューク新体制下では、 2009 年チリの D\&S 買収による進出、2010 年のインドのバルディとの合弁による卸売 進出、2011 年のマスマートへの $51 \%$ 出資で の進出と続き、更なる出店の噂が絶えない状 況にある。メキシコ事業におけるスキャン ダルの影響がじうなるか予断は許さないが、 中長期的には今後も新興市場重視路線は変 更されないとみられる。

(3)ウォルマートの国際市場参入戦略

\section{a. 国際市場参入戦略の概要}

ウォルマートの本格的な海外進出は 1991 年に開始された。初期の香港からの撤退 (1995 年)、インドネシアからの撤退 (1997 年)、試行錯誤期の韓国、ドイツからの撤退 (2006 年) を経て、現在の出店国は北米のカ ナダ、メキシコ、中米 5 か国、中南米のブ ラジル、アルゼンチン、チリ、アジアの中国、 日本、インド (卸のみ)、欧州の英国、アフリ カ 13 か国である (表 1 参照)。

表1 ウォルマートの国際市場参入の経緯及び店舗数の推移 注5）

\begin{tabular}{|c|c|c|c|c|c|c|c|c|c|c|c|c|c|c|c|c|c|c|c|c|}
\hline 参入国 & 参入経緯 & 1994 & 1995 & 1996 & 1997 & 1998 & 1999 & 2000 & 2001 & 2002 & 2003 & 2004 & 2005 & 2006 & 2007 & 2008 & 2009 & 2010 & 2011 & 2012 \\
\hline メキシコ & シフラと合并 & 24 & 97 & 126 & 152 & 402 & 416 & 458 & 499 & 551 & 597 & 623 & 679 & 774 & 889 & 1.023 & 1,197 & 1.469 & 1,730 & 2,088 \\
\hline カナダ & ウールコを買収 & & 123 & 131 & 136 & 144 & 153 & 166 & 174 & 196 & 213 & 235 & 256 & 278 & 289 & 305 & 318 & 317 & 325 & 333 \\
\hline フラジル & ロス・アメリカーナと合弁 & & & & 5 & 8 & 14 & 14 & 20 & 22 & 22 & 25 & 149 & 295 & 299 & 313 & 345 & 434 & 479 & 512 \\
\hline アルゼンチン & ゼロからの進出 & & & & 6 & 9 & 13 & 13 & 11 & 11 & 11 & 11 & 11 & 11 & 13 & 21 & 28 & 43 & 63 & 88 \\
\hline 中国 & 現地資本と合弁 & & & & 2 & 3 & 5 & 6 & 11 & 19 & 26 & 34 & 43 & 56 & 73 & 202 & 243 & 279 & 328 & 370 \\
\hline ト゚ッ & ベルトかウフを賈収 & & & & & 21 & 95 & 95 & 94 & 95 & 94 & 92 & 91 & 88 & 0 & 0 & 0 & 0 & 0 & 0 \\
\hline 暲国 & マクロの合升事業志買収 & & & & & & 4 & 5 & 6 & 9 & 15 & 15 & 16 & 16 & 0 & 0 & 0 & 0 & o & 0 \\
\hline 英国 注1） & アズタを買収 & & & & & & & 232 & 241 & 250 & 258 & 267 & 282 & 315 & 335 & 352 & 358 & 371 & 385 & 541 \\
\hline 日本 & 西友に資本参加 & & & & & & & & & & & & & 398 & 392 & 394 & 371 & 371 & 414 & 419 \\
\hline 中米5国 注2) & CARHCOと合并 & & & & & & & & & & & & & & 413 & 457 & 502 & 519 & 549 & 622 \\
\hline FI) & D\&Sを買収 & & & & & & & & & & & & & & & & 197 & 252 & 279 & 316 \\
\hline インド＼cjkstart注3) & バルティ・グループと合算 & & & & & & & & & & & & & & & & & 1 & 5 & 15 \\
\hline 南アフリカカ他 注4) & マスマートに資本参加 & & & & & & & & & & & & & & & & & & & 347 \\
\hline
\end{tabular}

注1) 英国は2011年にデンマークのダンスク社より英国内の小型店舗を買収したため、 2012年の数值が急増している。

注2)中米は5か国合計の数值である。

注3)インドは卸のみである。

注4)アフリカは南アフリカ305店舗、モザンビーク17店舗、ボツワナ11店埔及びその他9 か国の14店舗の合計の数值である。

注5) 2011年第2四半期より国際部門からプエルトリコは国内部門に統合された。なお、統 合された2011年度のプエルトリコの55店舗の内訳はスーパーセンター9、ディスカウント ストア7、ネイバーフッドマーケット29、サムズクラブ10であった。 (出所) ウオルマートの各年度年次報告書及び2012年の数值については同社プレスリリー スの内容に基づいて、筆者が作成。 
進出国の中では、ウォルマートの新興市場 モデルのプロトタイプとなりつつあるメキ シコでの成功は圧倒的である。2011 年英国 でのダンスク社からの英国国内 147 店舗買 収のような、大型買収がなされた数年を除い て、常に店舗数増加の過半数はメキシコにお いてである。その他の市場では、適切な追 加買収によって現地におけるボジションの 向上を果たしたブラジルと中国の成長が目 立って打り、有力市場に打ける追加買収が今 後もなされていくものとみられる。

\section{b. 国際市場参入方法}

ウォルマートが国際市場参入に際して採 用した方法は 3 つある。

第 1 の方法は現地企業の買収による進出 である。この方法はカナダ、韓国、ドイツ、 イギリス、チリで採用された。これらの諸国 は相対的に小売産業が成熟した国であり、既 にライバルが多数存在し、彼らが多くの有望 立地を押さえているため、ある程度競争力を 持った企業を買収することによって対抗可 能な店舗を迅速に確保するために、この方法 が採用されたのである。

第 2 の方法は合弁による進出である。こ の方法はメキシコ、ブラジル、中国、韓国、 日本、中米、インド、南アフリカ他 ${ }^{7}$ で利用 された。この方法は当初進出先に規制や独特 の慣習がある場合に採用されてきた。

第 3 の方法はゼロからの出店である。この 方法はアルゼンチンで採用された。発展途上 国である同国では、現地に適当なパートナー が見つけられなかったために、ゼロからの出 店を行ったのである。

ウォルマートは以上 3 つの方法を採用し て市場参入を行ってきたわけであるが、以下 の理由から今後合弁後買収というメキシコ で最初になされたゆえに、メキシコ方式と呼 ばれる方法の比重が高まると予測される。
第 1 に、BRICS など有力新興市場では規 制緩和を待って参入したのでは、出遅れる可 能性が高いからである。このことは有力新興 市場の代表であるインドの状況の検討から も明らかである。ウォルマートだけでなくカ ルフールもテスコも、規制がある程度残って いる状況でも、現地パートナーとの合弁を用 いるなど規制回避するための取り組みを行 うことによって、将来への布石を打ってきて 打り、受け入れる現地企業も一定のレベルま で力をつけてきている。

第 2 に、進出候補先となりうる新興市場 では、ゼロからの出店を促していた要因であ る現地に適当なパートナーがいないという 可能性はもはや低いからである。ウォルマー トが近年進出を決めた諸国のうち、中米では アホールドが既に進出済みであったし、イン ド、南アフリカ他でも同社のパートナーとな りうる経営資源を有する地元有力企業が存 在していた。グローバル化が進み、少しでも 機会がある市場を探索する傾向が強まる状 況下に打いては、ウォルマートが進出候補と するような新興市場では、有力パートナーの ライバルとの争奪戦が起こることがあるに しても、候補自体が存在しないということは 考えづらくなっているといえる。

同社は成熟市場となった本国米国と新興 市場の市場特性の相違を踏まえて、新興市 場重視の参入市場決定と即買収あるいは合 弁後買収といった参入方法の決定によって、 買収あるいは合弁を行う現地パートナーの 資産を基盤とした、小売事業モデル移転のパ ターンを確立しつつある。

\section{c. 進出市場での出店戦略及び業態戦略}

ウォルマートの出店戦略は、買収先として 選択する大手小売業者が、新興国での都市化 に対応して台頭する都市部の中間階層を主 要標的としていることが多いため、当初買収 
先と同様に大都市での出店を行っていた。し かし、近年では標的階層を段階的に中の下な いし下の上あたりに拡大するために、出店地 域を大都市郊外や中小都市へと拡大してい く傾向がみられる。

業態戦略は買収先の有する既存業態を活 用しつつウォルマートが獲得してきたノウ ハウを段階的に導入し、スーパーセンターや サムズクラブへの名称変更をも含めて転換 してきた。しかし、近年では名称変更といっ たこだわりは捨てられ、パートナーがこれま で築いてきたブランド名を活用しながら、ノ ウハウの移転によって実質的にはスーパー センターや会員制倉庫型店舗への転換を進 める傾向が強まりつつある。

また、標的の下方へのシフトを進めるため に、メキシコのボデーガに象徴される新興市 場向け業態のノウハウをより積極的に導入 し、現地での更なるアレンジを行い、新規業 態開発を含む、よりダイナミックな戦略も採 用している。

\section{d. 進出市場での商品調達及び商品供給}

商品調達は現地パートナーの既存チャネ ルの活用を前提としつつ、出店地域の拡大や 業態のアレンジを進め、プライベート・ブ ランドの割合を高めている。そのプライベー
ト・ブランドには、グレートバリュー、ジョー ジ、メインステイズなどグローバルに展開し つつある全社的なブランドだけではなく、現 地パートナーが開発してきたプライベート 。 ブランド、ブラジルにみられるような現地 市場向けにウォルマートの有する商品調達 ネットワークを活用して新規に開発したブ ランド、現地の先進的農家からの産直品、中 米にみられるような近隣諸国で開発された ブランドなど、その開発形態も多様である。

商品供給は低コスト化を目指した IT や配 送センターなどのインフラに対する設備投 資を積極的に行いながらも、新興市場の特徴 である人件費の安さなども考慮したアレン ジを加えている。出店地域拡大や業態アレン ジが進むにつれて、プライベート・ブランド の提供を行うパートナーを含めた取引相手 への働きかけも強めている。

\section{e. 国際化に伴う組織体制の整備}

同社の組織体制も国際部門拡大に対応し て、従来の国際部門の下に各国が並列に並ぶ といったフラットな組織体制から移行し、ダ グ・マクミロン国際部門 CEO が統括する国 際部門の下に、アジア、ラテンアメリカ、そ の他地域の統括部門を設置し、世界 3 極体 制を鮮明にしつつある(図 2 参照)。

\section{図2 ウォルマートの組織体制}

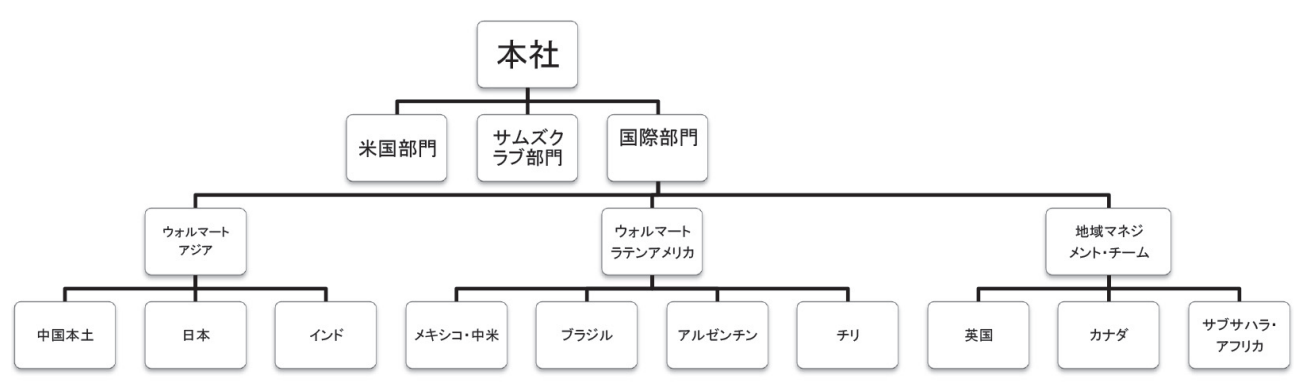

（出所）ウオルマートが提供する情報に基づいて、筆者が作成。 
同社の国際部門の本格再編は 2008 年 9 月 の中国本土、日本、インドを統括するアジア 地域本社 (Regional Headquarters) の香港設 立に始まる。 2009 年 9 月、ウォルマート・ アジア社長兼 $\mathrm{CEO}$ に、日本駐在経験もある DHL エキスプレスのスコット・プライスを 招聘した。

2010 年 2 月 23 日にはメキシコ、中米 5 か国、ブラジル、アルゼンチン、チリを統 括するラテンアメリカ地域事務所 (Regional Office)が米国の南フロリダに設立された。新 設のウォルマート・ラテンアメリカ社長兼 CEO には、エドゥアルド・ソロルサーノが 就任した。彼はウォルマートが買収したメキ シコのシフラ社出身でメキシコ事業成功の 立役者の一人である。

2011 年 9 月 28 日には、カナダ、英国及び サブサハラ・アフリカの小売事業を指導し、 欧州、中東、アフリカ及びカナダにおける 海外事業開発を担当する地域マネジメント チーム (Regional Management Team)の設置 が発表された。新設のチームトップの上級副 社長兼地域マネジメントチーム社長兼 CEO には、デイビット・チーズライトが就任した。 彼は英国のアズダ出身でウォルマート・カナ ダの社長兼 CEO であった人物である。

3 極それぞれに各地域での実績を有する実 力者を配し体制が確立されつつある中で、こ れからは米国本社、国際部門、各極に設立さ れた本部、中米、サブサハラ・アフリカといっ たサブ地域、各国といった多階層化された組 織間での連携が活発化することが予想され る。
（2）ウォル・メックスにみる新規業態開発志 向の現地化戦略

(1)ウォルマートのメキシコ市場参入の経緯

ウォルマートは 1991 年に現地最大の小売 業者であったシフラ社との合弁という方式 でメキシコ市場に参入し、NAFTA 発効によ る経済成長の中で、シフラ社の既存業態であ るアウレラ、スペラマ、スブルビア、ビップ スを中心に事業展開を行っていった。

ウォルマートも進出当初から成功したわ けではなく、物流システム未整備といった商 品供給に関する問題や輸入品にスペイン語 表示義務を課すといった商品調達に関する

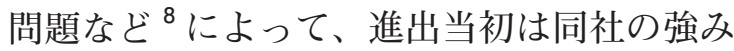
を十分に活用できず、苦戦を強いられた。

しかし、1995 年の通貨危機が状況を一変 させた。1997 年にウォルマートはシフラ社 を買収し、2000 年には社名もウォルマート ・デ・メヒコ(略称ウォル・メックス) と変更 し、全国展開を加速した。2002 年には民間 部門においてメキシコ最大の雇用主となり、 観光産業全体を上回る規模の売上高となっ た。

展開業態も社名変更前はシフラ社の地盤 であった首都圈を中心に 36 店舗展開してい たアウレラという伝統ブランドで大型スー パーを展開していたが、スーパーセンター及 びサムズクラブといった自社開発のディス カウント業態へと転換し、ウォルマートによ る支配がより明確となった(図 3 参照)。 
図3 ウオル・メックスの各業態の標的階層

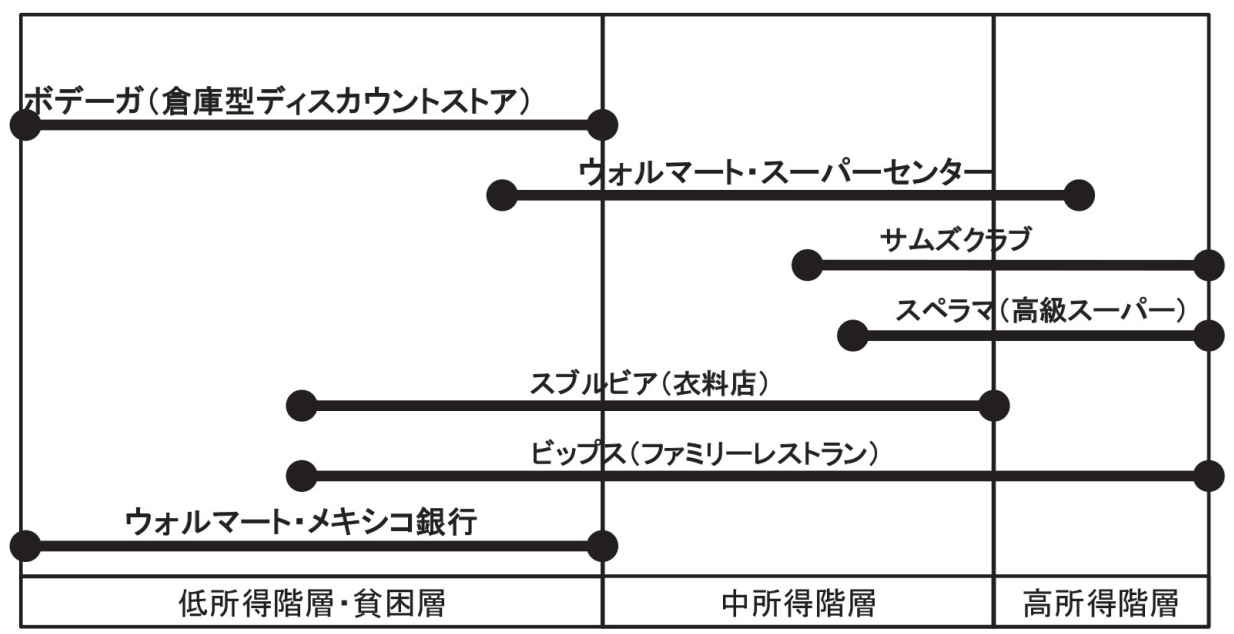

(出典)『日経ビジネス』2009年7月27日号の図を、筆者が修正加筆。

\section{(2)ウォルマートのメキシコ市場参入戦略}

同社のメキシコ市場参入戦略をまとめる と以下のようになる。参入市場選択に際して は、母国との近隣性と NAFTA 締結に向け た経済開放政策が主な要因となったといえ る。メキシコ市場は同社にとって初の本格的 な海外進出であり、近隣諸国選択は自然な行 為であった。このことは従来の小売国際化研 究でも示されており、同社のメキシコ以降の 進出先として地理的距離が近いカナダが選 択されていることからもわかる。

参入方法は合弁後買収である。この方法を 当初用いることによって、同国で根強い反米 感情や現地市場や現地企業からの反発をあ る程度回避することができた。当初しばらく は合弁による現地市場理解を進めた上で、経 済状況が悪くなったタイミングで買収を行 うことによって、反発を回避しつつ有利な条 件での買収が可能となった。まさに、先進諸 国に比べて相対的に不安定な新興市場経済 の特性をうまく利用した方法ともいえ、メキ シコ方式と呼ばれる新興市場進出の同社の 定番の方式となった。

業態及び出店戦略は当初は合弁パート ナーとの協調を前提に、同社の業態のうちア
イテム数も少なく出店が容易とみられたサ ムズクラブの展開を 1991 年に開始し、海外 出店の主力業態となるスーパーセンターと ともに、合弁パートナーのシフラ社があまり 進出していない地方の中心都市に展開した。

商品調達及び商品供給戦略は店舗網の拡 大にあわせて改善した。商品調達は当初業態 ごとに比重に差はありながらも、合弁先の ネットワークを主に活用していたが、ウォル マートの調達網の活用も段階的に進めた。

1997 年半ばまでにメキシコシティに物流 センターを設置し、メキシコのトラック運 送業者 EASO 社と米国のトラック運送会社 MS Carriers 社との 3 社でパートナーシップ を構築した。NAFTA により北米市場への供 給基地となったメキシコ国内からの商品供 給網を構築して、商品調達及び商品供給体制 を整備し、製品ミックスもメキシコ小売市場 の特性に合わせていった（Hill 2004、p.395）。 1997 年には合弁パートナーであったシフ ラ社買収を行い、2000 年には、社名のウォ ルマート・デ・メヒコ（略称ウォル・メック ス）への変更と前後して、胸のネームプレー 卜から教育研修まで従業員にウォルマート 職員としての意識を強める施策を講じると 
同時に、シフラ社の主要業態であったアウレ ラをウォルマート・スーパーセンターに名称 まで変更するなど、ウォルマートの国際部門 の一部であるという位置づけを明確にして いつた。

(3)新規業態開発志向現地化段階への転換

ウォルマートは初の本格的海外進出後約 10 年の市場参入段階において、非常に巧み
な事業展開により、メキシコにおいて根強く 存在する反米感情を撥ね退けて定着し、現地 適応化戦略を本格的に導入する新たな段階 に入った。その象徵的な戦略が倉庫を意味す るボデーガと呼ばれる倉庫型ディスカウン スストアの全国展開（表 2 参照）とその後 の更なる業態細分化である（表 3 参照）。

表2 ウオル·メックスの各業態の店舗数の推移

\begin{tabular}{|l|r|r|r|r|r|r|r|r|r|r|}
\hline & 2002 & 2003 & 2004 & 2005 & 2006 & 2007 & 2008 & 2009 & 2010 & 2011 \\
\hline ボデーガ & 116 & 140 & 162 & 203 & 258 & 313 & 442 & 684 & 899 & 1,204 \\
\hline ウォルマート & 75 & 83 & 89 & 105 & 118 & 136 & 153 & 169 & 192 & 213 \\
\hline サムズクラブ & 50 & 53 & 61 & 69 & 77 & 83 & 91 & 98 & 108 & 124 \\
\hline スペラマ & 44 & 44 & 48 & 55 & 60 & 64 & 67 & 69 & 75 & 88 \\
\hline スブルビア & 50 & 52 & 50 & 53 & 62 & 76 & 84 & 86 & 90 & 94 \\
\hline レストラン & 244 & 252 & 268 & 286 & 311 & 348 & 360 & 360 & 366 & 364 \\
\hline 合計 & 579 & 624 & 678 & 771 & 886 & 1,020 & 1,197 & 1,466 & 1,730 & 2,087 \\
\hline
\end{tabular}

(出典)メキシコ及び中米ウォルマート社の2011年アニュアルレ ポートの内容に基づいて、筆者が作成。

\section{表3 ウォル・メックス各業態店舗数と2011年開店数}

\begin{tabular}{|l|r|r|}
\hline 業態名 & 2011年末店舗数 & 2011 年開店数 \\
\hline ボデーガ全体 & 1,215 & 365 \\
\hline ボデーガ & 385 & 42 \\
\hline ミ・ボデーガ•アウレラ & 231 & 60 \\
\hline ボデーガ・アウレラ・エクスプレス & 599 & 208 \\
\hline スーパーセンター & 213 & 21 \\
\hline サムズクラブ & 126 & 16 \\
\hline スペラマ & 88 & 13 \\
\hline スブルビア & 94 & 4 \\
\hline レストラン & 365 & 1
\end{tabular}

注) 後に発表されたアニュアルレポートとの数値が若干異なっている。 (出典) メキシコ及び中米ウオルマート社の2011年第4四半期レポートの内容に基づ いて、筆者が作成。

ボデーガ業態は買収したシフラが現地の 低所得者に向けて開発していた業態をべー スとしたものである。現在のボデーガは名称 こそ現地文化尊重という意味合いもあり維 持しているが、ウォルマートが現地市場特性
である低価格への強い欲求に対応し続けて おり、シフラを買収した当時とはかけ離れた ものになっている。

ボデーガはスペイン語で倉庫を意味し、買 収時には倉庫のような最低限度の内装設備 
の店舗での発展途上国ならではの安価な人 件費を活かした人海戦術によるロー・コス ト・オペレーションによって、若干の低価格 を実現する小売業態であった。ウォルマート 買収後、倉庫といったコンセプトを維持しつ つも同業態の多店舗展開を通じてサプライ チェーンの効率化を行い、低価格プライベー ト・ブランドを強化し、グループ全体のメー カーとの交渉力を活かしたナショナル・ブラ ンドの低価格化への取り組みを積極化し、供 給調達全てを含む小売事業モデルの現地適 応化を内包したウォルマートの新規開発業 態となったのである。

ウォルマートは同社主導が明確となった 2000 年以降、地方大都市への出店が一巡し、 シフラの中心業態であるアウレラの整理が 終わるのと前後して、ボデーガの低所得階層 取り込みに打ける有用性を確信し、1999 年 から 2004 年までの 6 年間で 17 州 39 都市に 新規出店を行った。ボデーガの出店は中産階 層の割合が少ないと考えられていた中規模 以下都市へも半ば強引に拡大された ${ }^{9}$ 。

さらに、現地適応化の取り組みを継続しボ デーガ業態の細分化が開始された。2004 年 11 月には、プエブラ州の州都プエブラ市郊 外の人口約 25,000 人の小規模都市であるテ カマチャルコ (Tecamachalco) に、ボデーガ より小規模の非会員制倉庫型業態であるミ。 ボデーガ・アウレラ (Mi Bodega Aurrera) を出店したのを皮切りに、より小規模都市へ の出店を開始した。

典型的な事例としては、2010 年 9 月 7 日 に開店した人口 1 万 5,000 人弱の小規模都市 カルキニへのミ・ボデーガ・アウレラ出店が あげられる。ユカタン半島の主要都市メリー ダとカンペチェの間に位置するカルキニは 小売産業の近代化が遅れているといわれる メキシコ南東部に位置しているが、南東地区
の主要都市ではない同都市への出店は、現在 の同社の出店戦略を象徵的に示している。

同社の取り組みはさらに加速し、小型のミ ニスーパーであるボデーガ・アウレラ・エク スプレスを開発し、コンビニエンスストアと 競合する大都市の隙間立地に出店するなど、 ボデーガ業態の中での細分化とアレンジを 積極的に行っている ${ }^{10}$ 。

ボデーガの店舗数は 2002 年の 116 店舗 から 2011 年には 1,204 店舗と 10 倍になり、 同社のメキシコにおける売上に占める比率 も 1999 年には約 $23 \%$ であったが、2009 年 には $35.6 \%$ となっており、スーパーセンター $27.8 \%$ 、サムズクラブ $26.5 \%$ 、スペラマ $4.9 \%$ 、 スブルビア $3.3 \%$ 、レストランビップス $1.9 \%$ を大きく上回っている。

その出店都市数もスーパーセンター 64 都 市、サムズクラブ 60 都市に対して、ボデー ガが 244 都市に達して打り、ボデーガの 2011 年の出店数の攻勢をみても、ミ・ボデー ガ・アウレラやボデーガ・アウレラ・エクス プレスを用いて、大都市郊外の新興都市や従 来出店しなかった中小都市への出店が進ん でいることがわかる。

なお、ウオルマートはテオティワカン近隣 への出店時の配慮にみられるように、従来か らメキシコ人の米国への屈折した感情を意 識して対応してきたが、ボデーガの出店地域 の拡大は地元への影響がさらに大きいこと から、地域社会への配慮をよりきめ細かく行 うようになってきており、特に景観への配慮 には細心の注意を払っている。

例えば、 2010 年 8 月 3 日開店のキンタナ ロー州トゥルム店は同地域が人気の観光地と なりつつあるため、景観維持政策に対応して 壁面を茶色にし、2011 年 5 月 17 日開店の工 カタン州イサマル店は街並みが黄色で統一さ れているため、壁面を黄色にしている ${ }^{11}$ 。 


\section{4. 創造的な連続適応型の新規業龍開発志 向現地化戦略}

(1)ウォルマートの国際化戦略のリード市場 であるメキシコ市場

ウォルマートの国際化は既述の国際化の区 分では第 4 期の新興市場重視期 (2006 年〜)に 入ってから 6 年を経ている。本稿で主に検討 したメキシコ市場は同社の国際化において最 初の進出先であり、常にウォルマート国際化 のリード市場としての役割を果たしてきた。

同社はメキシコ市場に国際化の初期参入 期 (1991 ～ 1994 年) に参入し、世界市場焦 点期 (1994 〜 1999 年) には反米感情を巧み に回避しながら合弁企業から子会社への転 換を図った。戦略視点期 (1999～2005 年) には前期までの経験から実感したメキシコ の市場特性である、圧倒的規模を有する低所 得階層のニーズに徹底的に向き合い、新規業 態開発を行った。倉庫のような最低限度の内 装設備の店舗というハードを、発展途上国の 特徴である安価な人件費を活かした人海戦 術というソフト上の工夫によって運営する
ことによって、ロー・コスト・オペレーショ ンを実現し、若干の低価格を実現するという メキシコ発の元のアイデアを活かしながら、 ウオルマートがこれまで培ってきた低価格 $\mathrm{PB}$ の供給などの商品調達、サプライチェー ンの効率化などの商品供給、といったノウハ ウを移転し、ボデーガという新規開発業態の 導入を図り、更なる業態細分化に象徵される 現地適応化戦略を促進した。新興市場重視期 （2006 年〜）には重点地域である新興市場へ の開発業態の移転や、新興市場同様に低所得 階層が増加する英国など先進諸国市場への ノウハウ移転の可能性を模索しつつある ${ }^{12}$ 。

図 4 はウォルマートの国際化に関して図 1 で用いた小売事業モデルの枠組みに基づいて まとめたものである。小売業務の方針の相違 は、母国市場とリード市場メキシコでの方針 の相違が他国に打いても踏襲されたものであ る。方針が母国市場と同一の商品調達・商品 供給・取引関係についても、方針に基づいた 適応化に関しては、メキシコ市場での成功に 引っ張られる形で進展してきている。

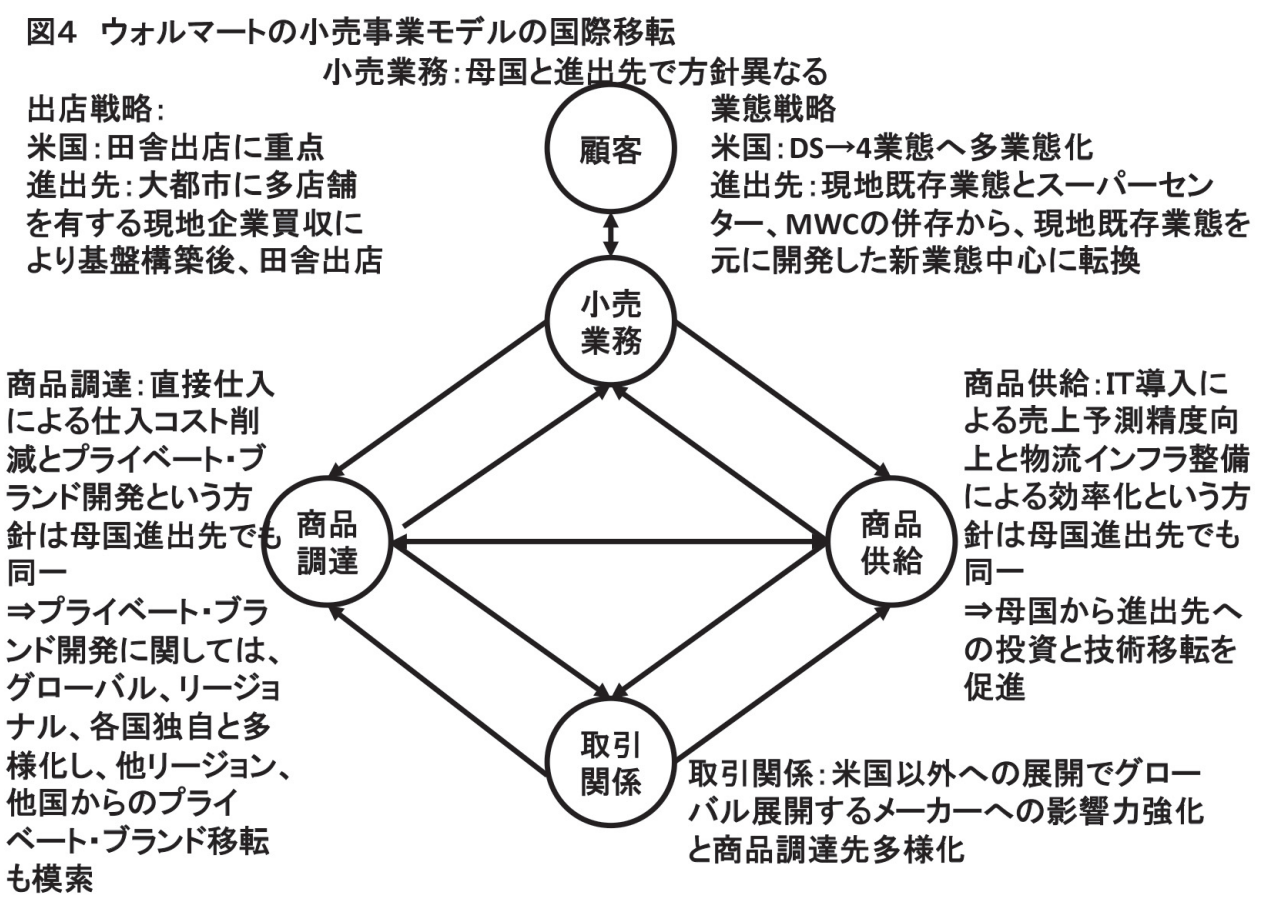

(出所) 矢作 $(2007 、 34$ 頁)の枠組みに基づいて、筆者が作成。 
(2) 創造的な連続適応型の新規開発業態志向 現地化戦略

矢作 (2007、259 頁) はテスコの国際化事 例においてタイの役割を、現地子会社を取り まとめ、べストプラクティスを提供するアジ ア国際化センターとして位置づけている。そ れに対して、メキシコ市場はウォルマートが 組織改革によって分割した 3 地域のうちの 1 地域であるラテンアメリカに存在する現地 子会社を取りまとめるに留まらず、新興市場 全体にベストプラクティスを提供する新興 市場向け国際化センターといえる。

矢作 (2007、242 頁) はテスコの国際化事例 分析を行った章のサブタイトルを「業態戦略 は参入市場にしたがう」とし、国際化に有効 なフォーマットとしてハイパーマーケット を選択し、国際化事業の柱として開発したこ とを検討することによって、「既存業態移転」 型ではなく、「新規業態開発」志向であると 述べている (矢作 2007、248 頁)。

また、矢作はセブンイレブンの日本市場参 入事例を、米国から移転された基本業態コン セプトを継承した上で、同社にとってリード 市場となった日本市場の文脈に合わせて磨 きあげる過程を「創造的な連続適応」として 提示している (矢作 2007、84-101 頁)。

本稿は、ウォルマートが、進出先である メキシコ市場では普及していなかったスー パーセンターやサムズクラブといった既存 業態で新規市場参入した後に、国際化のリー ド市場であるメキシコで発見したボデーガ という業態の基本コンセプトを維持しつつ も、新興市場としての市場文脈に合わせて磨 きあげる「創造的な連続適応」を行うことに よって新業態として開発し、その他の新興市 場進出の柱にしようとしていることを明ら かにした。これは、リード市場創造的連続適 応型の新規業態開発志向現地化戦略と言え
るものである。

矢作の上記分類は、小売事業モデルの現地 化プロセスに扔いて小売業務が先行し、商品 調達・商品供給が後に続くという各システム 間の相互依存関係の序列性に着目して分類し ている (矢作 2007、39-40 頁)。本稿ケースで も小売業務の先行はみられており、序列性に 関する指摘と序列性を踏まえて、基本業態コ ンセプトを維持しながら、進出後の現地適応 度によって現地化戦略パターンを、(2)(標準 化のなかの部分適応) - (3) (創造的な連続適応) に分類したことについては、筆者も同意する。

しかし、矢作の(2) (標準化のなかの部分適 応) ・ (3) (創造的な連続適応) と (4) (新規業態開 発志向)の分類に関しては、本国からの進出 時の分析しか反映されておらず(矢作の分類 では、基本コンセプトを維持するか、参入市 場に合わせて開発するか)、創造的な連続適 応による進出後の現地適応度に関して、矢作 は分析しておらず、当然分類にも反映されて いない。

本稿ケースで分析したメキシコ市場に打 ける新規業態開発のプロセスは、進出時と進 出後の両時点で現地適応度が高いケースな のである。同ケースは進出時の現地適応度に 関しては、商品供給・商品調達・取引関係を 変化させることを強く意識しており、既述 の矢作の (3) (創造的な連続適応)のケースで あるセブンイレブンの日本進出で示した日 本型コンビニエンスストア開発に扎ける創 造的な連続適応のプロセス同様に高いとい える ${ }^{13}$ 。進出後の現地適応度の高さに関して も、矢作の示した(4)(新規業態開発志向)のテ スコのケースは基本業態コンセプトを参入 市場に合わせて開発しており、筆者のメキシ コのケースはリード市場であるメキシコ市 場に打いて発見したこととの相違があると はいえ、同様に高いといえる(図 5 参照)。 
図5 本稿ケースが示したパターンを含めた現地化戦略パターン

進出後の現地適応度

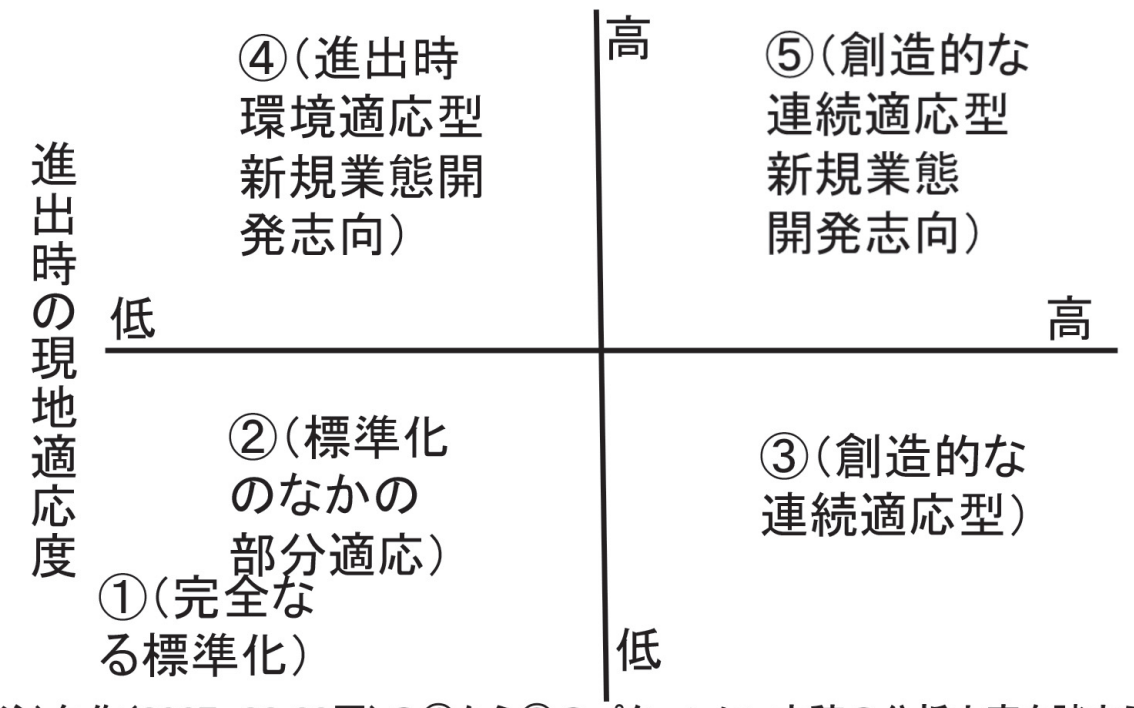

注) 矢作 (2007、38-39頁)の(1)から(3)のパターンに、本稿の分析内容を踏まえて、 矢作の (4)のパターンを修正し、(5)のパターンを付けくわえて、新たな枠組みで分類し た。

なお、(1) (完全なる標準化志向)に関して は、そもそも適応する意思が非常に弱いた め、当然(2) (標準化のなかの部分適応) と同一 象限に位置づけられる。

本稿ケースは、進出時と進出後両時点で の現地適応度の高い現地化パターンであり、 進出時の適応度に主に焦点を定めた(4)(新規 業態開発志向)に対して、5)(創造的な連続適 応型新規業態開発志向) 現地化パターンの事 例であり、矢作の示したテスコのケースは(5) (創造的な連続適応型新規業態開発志向)に 対して、(4)(進出時環境適応型新規業態開発 志向) 現地化パターンの事例といえるのであ る。

\section{5. 結び}

本稿は、ウォルマートのメキシコ市場現地 化ケースを分析することによって、新規業態 開発志向に創造的な連続適応による進出後 の現地適応度という新たな軸を設定するこ とによって、矢作の現地化パターンの 4 分 類のうち、(4) (新規業態開発志向) 現地化を
(4) (進出時環境適応型新規業態開発志向) 現 地化に修正し、(5) (創造的な連続適応型新規 業態開発志向) 現地化を追加した。

今後の研究課題としては、(5)(創造的な連 続適応型新規業態開発志向) 現地化過程の精 緻化と開発された新規業態の移転過程の解 明があげられる。

(5)(創造的な連続適応型新規業態開発志 向)現地化過程の精緻化に打いては、現在も 創造的な連続適応が進行中の先端事例であ る、ウォルマートのメキシコ市場現地化ケー スの分析を継続的に行う必要がある。ウオル マートのメキシコでの成功はグローバル・リ テイラーの新興市場の 1 市場の成功に留ま らないレベルに達している。人口 1 億を有 する巨大市場における競合他社の追随を許 さない成功事例はかつても存在せず、南アフ リカでの現地労組の反対、インドでの現地中 小小売業者の進出反対という状況を分析す れば、今後も現れる可能性は小さいことが 予測される。新興市場の特性を有する巨大市 場に打いて壮大な実験を行うことができる 
唯一の存在としてのウォルマートの立場は 分析対象としては貴重であり、継続的に分析 していく必要がある。

他社が(5) (創造的な連続適応型新規業態開 発志向) 現地化を行っていないかも探索して いく必要がある。グローバル・リテーラーの 母国市場は飽和状態となっており、彼らも当 然新興市場進出に関して、ウォルマートの現 地化パターンを意識して戦略立案を行うと みられる。ウォルマートと異なる(5) (創造的 な連続適応型新規業態開発志向) 現地化がな される可能性は十分にありうる。

開発された新規業態の移転プロセスの解 明に関しては、矢作もテスコの母国市場英国 とタイなど海外市場との知識移転について 分析した上で、国際ネットワークのなかでの 知識移転について触れ (矢作 2007、261-275 頁)、「現地化段階」から「グローバル統合」 段階への転換に伴う今後の研究課題として 国際知識移転研究の重要性について言及し ている(矢作 2007、271頁)。本稿ケースで 開発された業態の移転に関しては、新興市場 から新興市場の移転であり、市場間の類似性 は先進諸国と新興国の間よりは高いとみら れるが、新興市場間の類似性と相違の分析枠 組みを規定し、進出後の創造的な連続適応が 行いやすい条件に関する精緻化を行ってい く必要がある。

本稿では紙数の制約もあり、中国・日本・ インドで構成されるアジア、メキシコを中心 に中南米全域で構成されるラテンアメリカ、 カナダ・英国・アフリカで構成されるその他 の地域に 3 極化された組織改革について言 及するにとどまった。組織体制が整備された 後に本格化するとみられる新規開発業態の 移転プロセスに関しても詳細に分析してい く必要がある。

\section{〈注〉}

1 ウォルマートの既存外資と異なるアプローチ での現地化は、メキシコの現地市場へ絶大な 影響を及ぼしており、同社は現地市場への影 響の大きさに配慮して取り組みを行ってきた ため、現状では大きな問題にまでは発展して いない。しかし、反米感情はメキシコ人の意 識の根底に常にあり、同社の現地市場への影 響が拡大していけば、それに応じたよりしっ かりとした反米感情への配慮が求められるだ けに、同社の現地市場への影響に関しては今 後も注目していく必要がある。これまでの同 社のメキシコ現地市場への絶大な影響に関し て詳細は、丸谷・小松(2008)、丸谷 $(2009 b) 、$ 丸谷 $(2011 b)$ を参照。

2 本稿は、学術研究助成基金助成金 (基盤研究 (C) ラテンアメリカにおける新規業態開発志 向戦略モデル構築のための研究、課題番号 : 23530544、2011 〜 2013 年度) 及び、2011 年 度の東京経済大学個人研究助成費 (研究課題 番号 11-27) を受けた研究成果である。

3 ウォルマートも従来認めてこなかった市場飽 和の論調を、既存店売上高マイナスといった 状況において公的に認め手薄だった都市部進 出も踏まえて、ネイバーフッドマーケット 以来 13 年ぶりの新業態である小型食品スー パー「ウォルマート・エクスプレス」 1 号店 をアーカンソー州ジェントリーで 2011 年 6 月に開店したことにみられるように、新機軸 として小型店舗開発を重視するようになり、 食品スーパーのウォルマート・マーケットの 細分化も行い、一部の大規模タイプでは非食 品分野の品揃えを拡大し、アーカンソー州立 大学内にウォルマート・オン・キャンパスを 出店し、ヒスパニック対応型店舗「スーペル メルカード・デ・ウォルマート (Supermercado de Walmart)」の出店も開始している（丸谷 2012a)。 
4 これはBurt and Sparks (2006)の区分に、近 年の動向を踏まえて、第 4 段階として、新興 市場重視期を加えたものである。

5 社内では米国市場の世界の中での位置づけも 未だ強いため、米国国内のサムズクラブ部門 において飽和状態である同業態で着実な実績 をあげたアルバイトからのたたき上げで人望 の厚い人物を国際部門のトップに据え、将来 の後継候補としての準備とみせることによっ て、国内部門にも配慮したとみられる。

6 ウォルマートのメキシコ子会社ウォル・メッ クスをめぐるスキャンダルに関して詳細は、 ニューヨークタイムズ紙が 2012 年 4 月 21 日 付のトップ記事として報じた。同紙によれば、 ウォルマート本社が元幹部の内部告発を受け た調査において、メキシコ子会社の贈賄工作 をめぐる情報を把握したにもかかわらず、米 国とメキシコ両国の関係当局に通報しなかっ たとのことである。その後、2001 年 8 月から 2005 年 2 月までウォル・メックスを率いたエ ドゥアルド・カストロ・ライト副会長は 7 月 1 日付で辞任した。なお、ウォル・メックスは 6 月 20 日にはメキシコでの出店計画を当初の発 表より 60 -90 日の期間分遅らせ、結果とし て 2012 年の出店数は当初の予定の $410-436$ 店舗から $325-335$ 店舗に、投資額は当初の 予定の 197 億 4,000 万ペソから 174 億 8,000 万ペソになると発表している。詳細は、ニュー ヨークタイムズ紙 2012 年 4 月 21 日付 (http:// www.nytimes.com/2012/04/22/business/atwal-mart-in-mexico-a-bribe-inquiry-silenced. html?_r=2\&hp\&pagewanted=print)、メキシ コ Milenio 紙 6 月 21 日 付 (Mario Maldonado, “baja su inversion Disminye Walmart planes de expansion”.) 及びウォル・メックス 6 月 20 日 付プレスリリース (http://www.walmartmexico. com.mx/sala_de_prensa/operadoras/ walmartca/2012/junio/actualizacion-plan- expansion-2012.pdf) を参照。

7 現地大手小売業者マスマートは、南アフリカ を中心としつつも周辺国にも店舗を有してお り、南アフリカ国外の店舗も買収したため、 南アフリカ他とした。アフリカ進出に関して 詳細は丸谷 $(2012 \mathrm{a})$ を参照。

8 当時の苦戦に関しての詳細は、Hill (2004), p.394. 参照。

9 この時期の半ば強引な出店が注 6 で詳細に示 した買収というスキャンダルを引き起こした とみられる。

10 なお、ウォルマートはボデーガのアレンジに 加えて、ウォルマート銀行を設立し、従来ク レジットや銀行を利用してこなかった階層 への浸透も検討し始めている。ウォルマート でのクレジット利用はメキシコにおけるクレ ジット普及を促進しているといわれ、所得 の最下層である $20 \%$ のクレジット普及率は、 2000 年の $0.1 \%$ から 2005 年の $0.5 \%$ へと拡大 している。ウォルマート銀行は 2007 年に開 始され、2007 年 16 支店、2008 年 38 支店、 2009 年 190 支店と拡大され、2011 年末には 263 支店が営業を開始しており、同社のグルー プ店舗のうちメキシコシティ 267 店舗、隣接 するメキシコ州 237 店舗でもサービスを受 けることができ、今後更なる拡大がなされて いくとみられる。下の上や中の下に位置する 階層に対しては、クレジット利用の促進は有 用な戦略である。かなりの金額となっている 米国からの海外送金を考えれば、低所得階層 を引き付ける有用なサービスになるとみられ る。ウォルマートの多くの店舗には ATM が 設置され、薬局、均一店、メガネショップ、ファ ストフード店などが併設されており、顧客の 最低限度の利便性は充たしている。従来から 良質とはいえない生鮮食品の品揃え同様、今 後はこれらのレベルアップが課題である。低 コストを維持しつつ、どれだけより決め細や 
かな対応が可能であるのかの見極めが重要と なるとみられる。

11 近年のウォル・メックスの既存業態の革新に 関しては、現地で絶大なる支持を獲得してい るメキシコヤクルト社取締役の櫻井清孝氏他 多くの社員や取引先の皆様に営業同行インタ ビュー・工場視察など全面協力を頂き、ボ デーガ業態細分化や地元への配慮などに関す る現地調査においては、ユカタン自治大学大 学院人類学研究科の井堂彰人氏に同行して頂 き、現地調査後も貴重な資料の提供を頂いて いる。ここに記して感謝の意を表する。

12 筆者は 2012 年 9 月にウォルマートの英国子 会社アズダの全業態の現地視察を行った際 に、ウォルマートによる買収後展開するよう になり、2010 年 6 月のデンマークの大手小 売企業ダンスク・スーパーマークト (Dansk Supermarked) からのネットー (Netto) の英国 内店舗の買収後の業態統合により店舗が急増 した、 2 万 $5000 \mathrm{~m}^{2}$ 未満の小型ディスカウン トストアについても視察を行った。筆者が視 察した店舗はロンドンの郊外の低所得階層に 属するイスラム教徒の移民が多い地域に立地 していたが、その立地条件はボデーガを展開 する新興市場メキシコの環境に類似してお り、展開する業態もアズダに比較しても低所 得階層向けの PB や低価格 NB の品揃えに重 点が置かれていた。

13 矢作も田村 (2004) の内容に依拠しながら、 ウォルマートやテスコの欧米小売企業やセブ ンイレブン・ジャパンと日本の総合スーパー の収益モデルの相違を説明し、ウォルマート とセブンイレブン・ジャパンの適応化の展開 方法の類似性について言及している。ウォル マートとセブンイレブン・ジャパンの適応化 の展開方法の類似性についての言及に関して 詳細は、矢作 2007、352-353 頁を参照。

\section{〈参考文献〉}

(邦文)

相原修、嶋正、三浦俊彦 (2009)、『グローバルマー ケティング入門』、日本経済新聞出版社。

青木均 (2008)、『小売業態の国際移転の研究』、 成文堂。

川端基夫(2000)、『小売業の海外進出と戦略』、 新評論。

川端庸子(2011)、『小売業における国際電子調達 に関する研究』、明治大学大学院経営学研究科 2010 年度博士学位請求論文。

川端庸子(2012)、『小売業の国際電子商品調達 ウォルマート、アジェントリクス、シジシーの 事例を中心に』、同文館出版。

金亨洙(2008)、『小売企業のグローバル戦略と移 転』、文眞堂。

小松仁美、丸谷雄一郎(2009)、「メキシコシティ におけるストリートチルドレンの生活・労働場 所の所在および決定条件 -- メトロ駅周辺にお ける実態調査に基づいて」、『国際問題研究所紀 要』第 133 号、87-119 頁。

サム・ウォルトン他(2002)、『私のウォルマート 商法』講談社、2002 年。

鈴木安昭(1976)、「外国資本の進出とわが国の大 規模小売業」、『経済の国際化と中小企業』、有 斐閣、1976 年。

田村正紀(2004)、『先端流通産業 日本と世界』、 千倉書房。

深澤琢也、崔在濬、臼井哲也、内堀敬則 (2008)、 「小売企業の国際化における標準化一適応化戦 略についての一考察」『中央学院大学社会シス テム研究所紀要』、第 8 巻第 2 号、75-87 頁。 星野妙子(2010)、『メキシコのビジネスグループ

の進化と適応』、JETRO アジア経済研究所。 ボブ・オルテガ(2000)、『ウオルマート』、日経 $\mathrm{BP}$ 社。

丸谷雄一郎(2003)、『メキシコの経済開放と小売 業の変容』、白桃書房。 
丸谷雄一郎(2009a)、『ラテンアメリカ経済成長

と広がる貧困格差』、創成社。

丸谷雄一郎(2009b)、「メキシコの大手小売業者 ソリアナのウォルマートへの対抗戦略」、『東京 経大学会誌経営学』、第 264 号、49-71 頁。

丸谷雄一郎(2011a)、「ウォルマートのチリ市場

参入戦略」、東京経大学会誌経営学』、第 266 号、 37-54 頁。

丸谷雄一郎(2011b)、「ウォルマートの世界戦略

とメキシコ進出」、『現代メキシコを知るための

六○章』、明石書店、110-113 頁。

丸谷雄一郎(2011c)、「中米地峡市場におけるウォ ルマートの現地適応化に向けた取り組み」、『財 団法人貿易奨励会第 10 回 (2010 年度) 貿易研 究会研究報告書』、137-149 頁。

丸谷雄一郎(2012a)、「ウォルマートの新興市場 南アフリカへの参入戦略」、『東京経大学会誌経 営学』、第 274 号、179-204 頁。

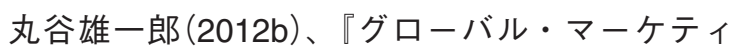

ング (第 4 版)』、創成社。

丸谷雄一郎、大澤武史 (2008)、『ウォルマートの 新興市場参入戦略 中南米で存在感を増すグ ローバル・リテイラー』、芙蓉書房。

丸谷雄一郎、小松仁美(2008)、「メキシコ合衆国 におけるストリート・ベンダーに関する一考察 一生活条件を向上させていくのが難しい階層の ライフヒストリーから」、『国際問題研究所紀 要』、第 132 号、73-99 頁。

向山雅夫 (1996)、『ピュア・グローバルへの着地』、

千倉書房。

矢作敏行 (1994)、『コンビニエンス・ストア・シ ステムの革新性』、日本経済新聞社。 矢作敏行 (2007)、『小売国際化プロセス』、有斐閣。

\section{(欧文)}

Alexander, Nicholas(1997), International Retailing, Blackwell Publishers.

Alexander, N and Myers, H.(2000), "The Retail
Internationalization Process",International Marketing Review,17(4/5),334-53.

Antad(2007), Directorio 2007,Antad.

Burt, Steve and Leigh Sparks(2006), "Wal-Mart's world", Wal-Mart World: the world's biggest corporation in the global economy, 27-43.

Brunn, Stanley D.(ed.)(2006), Wal-Mart World, Routledge.

Corstjens, Marcel and Rajiv Lal(2012), Retail Doesn't Cross Borders: Here's Why and What to Do About It,Harvard Business Review, 90(4). 104-111.

Diaz, Alejandro Jorge A.Lacayo, and Luis Saicedo(2007), “Selling to'mom-and-pop'stores in Latin America", The Mckinsey Quarterly 2007 Special edition:Shaping a new agenda for Latin America, 71-81.

Douglas, S. P. and C. S. Craig,(1995), Global Marketing Strategy, McGraw-Hill.

Durand, Cedric(2007), "Externalities from foreign direct investment in the Mexican retailing sector," Cambridge Jounral of Economics, 31(3), 393-411.

Galván, José Luis Álvarez and Chris Tilly(2006), "Lousy Jobs, Invisible Unions:The Mexican Retail Sector in the Age of Globalization", International Labor and Working-Class History, No.70, 61-85.

Hill, CharlesW.L.,(2004), "Wal-Mart's Mexican Adventure," Cases in strategic management (6thed.), Houghton Mifflin, 392-396.

Matusitz,Jonathan and Kristin Leanza(2011), "Asda:Organic Growth of Retailer in the United Kingdom?", Journal of International Food \& Agribusiness Marketing, 23, 128-150.

Mendoza, Jorge, Fernando Pozo and David Spener(2002), Fragmented Markets, Elaborate Chains:The Retail Distribution of Imported 
Clothing in Mexico, Free Trade and Uneven Development: The North American Apparel Industry After Nafta, Temple University Press.

Reardon, Thomas and Julio A.Berdegue(2002),

"The Rapid Rise of Supermarkets in Latin America," Development Policy Review, Vol.20, No.4, 371-388.

Reardon Thomas,C.Peter Timmer and Christopher B.Barrett(2003), "The Rise of Supermarkets in Africa, Asia and Latin America," American Journal of Agricultural Economics, Vol.85, 114046.

Sterquist, Brenda(2007), International retailing (2nd), Fairchild Publications.

Sterquist,Brenda(2011), Retail Stratigic International Expansion(SIRE2) Theory and Cases, BSC Publisher.

Thomas, Douglas E.(2007), “Grupo Gigante-2005,” Strategic Management Cases (11th ed.), Peason Prentice Hall, 302-311.

Thomas, Douglas E.and Fernan Gonzalez(2007), "Wal-Mart Mexico-2005", Strategic Management Cases(11th ed.), Peason Prentice Hall, 292301. (平野雅仁訳「ウォルマート・メキシコ 社 2005 年」『経営戦略ケース集』中央経済社、 2007 年。)

Vida, Irena and Ann Fairhurst(1998), "International expansion of retail firms: A theoretical approach for future investigations", Journal of Retailing and Consumer Services, Vol.5( 3), 143-151. 